\title{
Hubungan Perilaku Makan dan Konsumsi Tablet Fe dengan Kejadian Anemia pada Ibu Hamil di Kabupaten Fakfak Papua Barat
}

\author{
Kristiawan P. A. Nugroho ${ }^{1}$, Windu Merdekawati ${ }^{2}$, Julia Mariyani Hekakaya ${ }^{1}$
}

\section{Abstract}

Background: Anemia is associated with a condition of blood deficiency or low red blood cell count. Anemia during pregnancy is important to note because it concerns public health, especially maternal and child health.

Objective: This study was to determine the relationship between eating behavior, iron tablet consumption, and anemia incidence in pregnant women in three Health Center (Puskesmas) in Fakfak district, West Papua.

Methods: This study used quantitative method with cross sectional study design. The total samples were 55 respondents from Fakfak Kota Health Center, Dulanpokpok Health Center, and Danaweria Health Center.

Results: Not all pregnant women were found to be regularly taking Fe tablets with a significance value of Chi-Square test of 0.001 , so that unregulary consumption of Fe tablets can affect the incidence of anemia in pregnant women.

Conclusion: There is a relationship of consumption of Fe tablets with anemia during pregnancy, not eating behavior.

Keywords: Anemia, pregnant women, eating behaviour, Fe tablets, West Papua

\section{Pendahuluan}

Anemia adalah suatu keadaan dimana tubuh memiliki jumlah sel darah merah (eritrosit) terlalu sedikit. Sel darah merah mengandung hemoglobin yang berfungsi untuk membawa oksigen ke seluruh jaringan tubuh (Proverawati, 2011). Secara global

\footnotetext{
Afiliasi Penulis

1 | Program Studi Ilmu Gizi, Fakultas Kedokteran dan IImu Kesehatan, Universitas Kristen Satya Wacana Salatiga

2 | Program Studi Teknologi Pangan, Fakultas Kedokteran dan Ilmu Kesehatan, Universitas Kristen Satya Wacana Salatiga
}

\section{Korespondensi kepada}

K.P.A. Nugroho

kristiawan.nugroho@staff.uksw.edu prevalensi anemia ibu hamil di seluruh dunia mencapai sekitar 41,8 \%. Perkiraan prevalensi anemia ibu hamil di Asia sebesar 48,2\%, Afrika 57,1\%, Amerika 24,1\% dan Eropa 25,1\%. Anemia pada masa kehamilan penting untuk diperhatikan karena menyangkut kesehatan masyarakat khususnya kesehatan ibu dan anak. Anemia pada ibu hamil menjadi salah satu indikator pengukuran keberhasilan pembangunan kesehatan suatu bangsa, keadaan ini menggambarkan kemampuan sosial ekonomi dalam memenuhi kebutuhan kuantitas dan kualitas gizi masyarakat (WHO, 2008).

Data Riskesdas pada tahun 2013 di 33 provinsi di Indonesia dan 497 kota atau kabupaten menunjukkan proporsi anemia pada ibu hamil 
sebesar 37,1\% yakni ibu hamil dengan kadar hemoglobin kurang dari $11 \mathrm{~g} / \mathrm{dl}$, dengan proporsi yang hampir sama antara kawasan perkotaan 36,4\% dan pedesaan 37,8\% (Balitbang Kemenkes $\mathrm{RI}, 2013)$. Data kejadian anemia pada ibu hamil di Puskesmas Fakfak Kota pada bulan Januari Oktober 2016 menunjukan 84 kasus, sementara di Puskesmas Danaweria berjumlah 42 kasus, dan Puskesmas Dulanpokpok berjumlah 39 kasus. Kondisi kejadian anemia tersebut rata-rata berada pada rentang kehamilan trimester I dan II. Kondisi ini juga terjadi pada ibu hamil yang berusia antara 17 - 40 tahun serta rata-rata ibu hamil yang telah mempunyai anak $>1$.

Beberapa penelitian terkait hal anemia telah dilakukan. Ariyani (2016) menyebutkan bahwa terdapat hubungan bermakna antara kepatuhan konsumsi tablet Fe dengan kejadian anemia pada ibu hamil trimester III, namun tidak terdapat hubungan bermakna antara umur ibu, jumlah paritas, dan Antenatal Care (ANC) dengan kejadian anemia pada ibu hamil trimester III di wilayah kerja Puskesmas Mojolaban, Kabupaten Sukoharjo. Penelitian Zulaikha dan Umu (2015) menjelaskan data dari Puskesmas Pleret Bantul, Yogyakarta pada tahun 2015 menunjukan bahwa pola makan ibu hamil pada trimester ke III tergolong sedang yakni sebesar $50 \%$ dengan kejadian ibu hamil yang mengalami anemia ringan sebanyak 53,3\%. Berdasarkan hasil tersebut dapat disimpulkan bahwa terdapat hubungan pola makan dengan kejadian anemia pada ibu hamil trimester III.

Selama ini belum ada penelitian mengenai hubungan antara perilaku makan, konsumsi tablet Fe, dan kejadian anemia pada ibu selama kehamilan, khususnya di wilayah Kabupaten Fakfak, Papua Barat. Berdasarkan latar belakang tersebut, penelitian dilakukan untuk mengetahui hubungan antara perilaku makan dan konsumsi tablet Fe dengan kejadian anemia pada ibu hamil yang dilihat dari jenis makanan, frekuensi makan, porsi makan, dan kebiasaan makan di tiga Puskesmas di Kabupaten Fakfak, Papua Barat.

\section{Metode}

Penelitian telah dilakukan pada bulan Desember 2016 - Januari 2017 di tiga Puskesmas yang teridentifikasi ditemukan adanya kasus anemia pada ibu hamil yang terletak di Kabupaten Fakfak, Papua Barat, yakni di Puskesmas Fakfak Kota, Puskesmas Danaweria, dan Puskesmas Dulanpokpok. Metode penelitian yang digunakan adalah kuantitatif dengan desain studi cross sectional, yaitu untuk mengetahui hubungan perilaku makan dengan kejadian anemia yang diteliti dalam waktu bersamaan. Populasi penelitian adalah seluruh ibu yang tinggal di sekitar wilayah kerja Puskesmas Fakfak Kota, Puskesmas Danaweria, dan Puskesmas Dulanpokpok. Teknik pengambilan sampel yang dilakukan dalam penelitian ini adalah consecutive sampling dan besar sampel minimal yang digunakan pada penelitian ini adalah 30 responden. Kriteria inklusi adalah ibu hamil yang mengalami anemia berumur 17 - 40 tahun, hamil anak kedua atau lebih dengan usia kehamilan ibu antara trimester I - III, dan bersedia menjadi responden. Kriteria eksklusi adalah ibu hamil yang tidak mengalami anemia pada umur antara 17 - 40 tahun, tidak hamil anak kedua atau lebih dengan usia kehamilan ibu antara trimester I - III, dan tidak bersedia menjadi responden.

Data yang dikumpulkan adalah data primer berupa kuesioner dan data sekunder berupa catatan rekam medik dan buku KIA. Peneliti meminta kesedian responden untuk berpartisipasi dalam pelaksanaan penelitian. Bagi yang bersedia dan memenuhi kriteria penelitian diminta untuk menandatangani lembar persetujuan (Informed Consent) ataupun memberi persetujuan secara lisan, lalu mengisi kuesioner yang diberikan. Uji coba kuesioner dilakukan sebelum pengumpulan data untuk menilai validitas dan realibilitas reliabilitas kuesioner. Selanjutnya dilakukan pengumpulan data, kemudian data tersebut diedit, diberi kode, dientri, dan dicek kembali apakah ada kesalahan atau tidak (cleaning data validation) agar data siap untuk dianalisis. Data diolah dan dianalisis dengan menggunakan program komputer SPSS. Analisis data yang dilakukan, yaitu analisis univariat dan bivariat. Analisis univariat dilakukan untuk mengetahui distribusi frekuensi dan persentase tiap variabel yang diteliti, sedangkan analisis bivariat berupa analisis hubungan antara perilaku makan dan kejadian anemia pada ibu hamil 
menggunakan uji Chi-square dengan nilai kebermaknaan 0,05.

\section{Hasil}

Berdasarkan Tabel 1, populasi dalam penelitian ini adalah seluruh ibu hamil berjumlah 85 responden yang datang untuk memeriksakan diri ke Puskesmas Fakfak Kota, Puskesmas Fakfak Tengah, dan Puskesmas Dulanpokpok, sedangkan responden yang bersedia terlibat dalam penelitian ini berjumlah 55 responden. Pendidikan ibu hamil terbagi dalam rentang pendidikan SD sebanyak 8 responden, SMP 10 responden, SMA 21 responden, serta D3 dan S1 masing-masing sebanyak 2 dan 14 responden. Berdasarkan mata pencariannya, ibu hamil dengan pekerjaan PNS berjumlah 12 responden, wiraswasta 3 responden, petani 3 responden, dan Ibu Rumah Tangga (IRT) 37 responden. Umur kehamilan ibu berksiar antara 3 - 36 minggu dengan hasil pengukuran $\mathrm{Hb}$ berkisar antara 5 - 10,9 gr/dL. Hasil pengukuran kadar hemoglobin $(\mathrm{Hb})$ darah para responden menunjukkan bahwa sebagian besar responden (71\%) memiliki kadar Hb berkisar antara 8.9 - 10.9 $\mathrm{gr} / \mathrm{dl}$ (anemia ringan), sebanyak $27 \%$ respoden mengalami anemia sedang (5 - $8 \mathrm{gr} / \mathrm{dl})$, dan sebanyak $2 \%$ responden memiliki kadar $\mathrm{Hb}$ normal.

Pada Tabel 1 ditampilkan pula usia kehamilan responden mulai dari trimester I hingga III. Sebanyak $42 \%$ responden ( 23 orang) berada pada rentang usia kehamilan 13 - 24 minggu (trimester II), kemudian $40 \%$ responden ( 22 orang) berada di trimester ke III (usia kehamilan 25 - 36 minggu), dan 10 orang responden (18\%) berada pada rentang kehamilan trimester I ( 1 - 12 minggu). Berdasarkan hasil penghitungan terhadap Indeks Massa Tubuh (IMT), sebanyak 75\% responden termasuk dalam kategori normal, kemudian sebanyak $14 \%$ responden tergolong gemuk ringan, $7 \%$ responden dengan kriteria gemuk berat, serta masing-masing sebesar $2 \%$ responden termasuk ke dalam kategori kurus ringan dan kurus berat.

Hasil analisis data dengan menggunakan uji ChiSquare pada Tabel 2 menyatakan bahwa tidak ada hubungan antara variabel jenis makanan, frekuensi makan, porsi makan, dan kebiasaan makan dengan kejadian anemia ibu hamil di ketiga puskesmas di Kabupaten Fakfak (nilai signifikansi >0,05). Namun,
Tabel 1 | Distribusi karakteristik responden

\begin{tabular}{|c|c|c|}
\hline Karakteristik variabel & Jumlah & $\%$ \\
\hline \multicolumn{3}{|l|}{ Usia kehamilah } \\
\hline Trisemester I & 10 & 18 \\
\hline Trisemester II & 23 & 42 \\
\hline Trisemester III & 22 & 40 \\
\hline Jumlah & 55 & 100 \\
\hline \multicolumn{3}{|l|}{ Pengukuran $\mathrm{Hb}$} \\
\hline Normal & 1 & 2 \\
\hline Ringan & 39 & 71 \\
\hline Sedang & 15 & 27 \\
\hline Jumlah & 55 & 100 \\
\hline \multicolumn{3}{|l|}{ Pendidikan } \\
\hline SD & 8 & 14 \\
\hline SMP & 10 & 18 \\
\hline SMA & 21 & 38 \\
\hline Diploma & 2 & 4 \\
\hline Perguruan Tinggi & 14 & 25 \\
\hline Jumlah & 55 & 100 \\
\hline \multicolumn{3}{|l|}{ IMT } \\
\hline Kurus berat & 41 & 75 \\
\hline Kurus ringan & 1 & 2 \\
\hline Normal & 1 & 2 \\
\hline Gemuk ringan & 8 & 14 \\
\hline Gemuk Berat & 4 & 7 \\
\hline Jumlah & 55 & 100 \\
\hline \multicolumn{3}{|l|}{ Pekerjaan } \\
\hline Petani & 3 & 5 \\
\hline Ibu rumah tangga & 37 & 68 \\
\hline Pegawai Negeri Sipil & 12 & 22 \\
\hline Wiraswasta & 3 & 5 \\
\hline Jumlah & 55 & 100 \\
\hline
\end{tabular}

Sumber: Data primer, 2017

berdasarkan analisis yang sama pada Tabel 2 dapat diketahui bahwa nilai signifikansi untuk variabel perilaku kepatuhan dalam mengonsumsi suplemen Fe bernilai $0.001<0.05$, sehingga dapat disimpulkan bahwa perilaku mengkonsumsi suplemen berpengaruh signifikan terhadap kejadian anemia pada ibu hamil.

\section{Pembahasan}

Terdapat tiga Puskesmas di Kabupaten Fakfak seperti Puskesmas Fakfak Kota, Puskesmas Fakfak Tengah, dan Puskesmas Dulanpokpok yang menjadi pilihan layanan pusat kesehatan masyarakat dan mudah diakses oleh warga masyarakat di sekitar Kabupaten Fakfak. Puskesmas Fakfak dan Puskesmas Dulanpokpok 
Tabel 2 | Hasil uji Chi-square untuk variabel jenis, frekuensi, porsi, kebiasaan makan ibu hamil, dan konsumsi tablet Fe

\begin{tabular}{cccc} 
No & Variabel/Indikator & Asymp. Sig. (2-sided) & Keterangan \\
\hline 1 & Jenis makanan & 0,442 & Tidak ada hubungan \\
\hline 2 & Frekuensi Makan & 0,576 & Tidak ada hubungan \\
\hline 3 & Porsi Makan & 0,702 & Tidak ada hubungan \\
\hline 4 & Kebiasaan Makan & 0,104 & Tidak ada hubungan \\
\hline 5 & Konsumsi Tablet Fe & 0,001 & Ada hubungan \\
\hline
\end{tabular}

Ketentuan: Jika nilai Pearson Chi-square lebih besar dari 0,05 = tidak memiliki hubungan; jika nilai Pearson Chi-square kurang dari 0,05 = memiliki hubungan

berada pada distrik Fakfak, sedangkan Puskesmas Fakfak Tengah berada di distrik Fakfak Tengah. Jumlah total ibu hamil pada ketiga Puskesmas ini berjumlah 165 orang terhitung dari bulan Januari Oktober 2016.

Pada saat melakukan penelitian, peneliti menemukan beberapa kendala di Puskesmas Fakfak Tengah, seperti adanya masyarakat yang masih kurang peduli terhadap kesehatan ibu dan bayi sehingga pemeriksaan kehamilan hanya dilakukan satu kali selama masa kehamilan. Selain itu, ada pula beberapa ibu yang tidak datang sama sekali untuk melakukan pemeriksaan kehamilan sehingga pihak Puskesmas berinisiatif bekerjasama dengan bidan desa untuk datang langsung ke rumah ibu hamil yang tidak pernah memeriksakan kehamilannya tersebut. Ibu hamil secara ideal melaksanakan perawatan kehamilan maksimal $13-$ 15 kali, minimal 4 kali, yaitu I kali pada trimester 1 , 1 kali pada trimester II, dan 2 kali pada trimester III. Namun, apabila terdapat kelainan dalam kehamilannya, maka frekuensi pemeriksaan disesuaikan menurut kebutuhan masing-masing (Syari et al., 2015).

Pentingnya pemeriksaan kehamilan bagi tiap individu dipengaruhi oleh sikap dari tiap individu tersebut. Hasil penelitian Kusumastuti (2015) menyatakan bahwa responden yang memiliki sikap positif $(73,3 \%)$ cenderung teratur dalam melakukan pemeriksaan Antenatal Care (ANC) sehingga kondisi ibu dan janin selalu terpantau serta dapat pula meningkatkan kesehatan ibu dan janin yang dikandungnya (Francin, 2005). Penelitian Hendrayani et al. (2013) menyatakan bahwa frekuensi ANC memiliki hubungan timbal balik dengan pengetahuan ibu. Pengetahuan ibu bertambah baik dengan meningkatnya frekuensi pemeriksaan kehamilan karena pada pelayanan antenatal selain dilakukan pemeriksaan kesehatan juga diberikan konseling kesehatan dan gizi selama kehamilan.

Ibu hamil memiliki kebutuhan makanan yang berbeda dengan ibu yang tidak hamil karena ada janin yang tumbuh dan berkembang di dalam rahimnya. Kebutuhan makanan perlu dilihat bukan hanya dalam konteks porsi saja, melainkan harus ditentukan pula berdasarkan mutu zat-zat gizi yang terkandung di dalam makanan yang dikonsumsi, seperti karbohidrat, protein, lemak, vitamin, dan mineral, serta kecukupan dalam asupan cairan. Ibu hamil harus mendapatkan gizi yang cukup untuk dirinya sendiri maupun janinnya. Bagi ibu hamil, kualitas maupun kuantitas makanan yang biasanya cukup untuk kesehatannya harus ditambah dengan zat-zat gizi dan energi agar janin bertumbuh dengan baik. Kualitas dan kuantitasnya perlu ditingkatkan melalui pola makan dengan kebiasaan makan yang baik. Pola makan dan kebiasaan makan yang baik adalah menu seimbang dengan jenis bervariasi, contohnya kecukupan kalori (Ertiana et al., 2016). Asupan kalori selama kehamilan sebaiknya ditambah pada kisaran 300 - 400 kkal perharinya. Sebanyak $55 \%$ kalori dapat diperoleh dari seumber umbi-umbian serta nasi sebagi sumber karbohidrat, lemak nabati maupun hewani dipenuhi sebanyak 35\%, kebutuhan protein mencapai $10 \%$, serta dilengkapi dengan sayuran dan buahan.

Data penelitian menunjukkan hasil tidak ada hubungan secara langsung antara jenis makanan terhadap kejadian anemia. Hasil tersebut bertolak belakang dengan penelitian Wahyuningsih dan Sri 
(2013) yang menyatakan bahwa ada hubungan bermakna antara pola makan dengan kejadian anemia pada ibu hamil di BPM Desa Bogosari, Kecamatan Guntur Demak. Sebanyak 20 responden $(55,6 \%)$ di tiga Puskesmas di Kabupaten Fakfak termasuk dalam kategori pola makan yang tidak seimbang. Hasil penelitian tersebut memberikan gambaran bahwa pola makan ibu hamil belum memenuhi pola makan seimbang yang dikarenakan kurangnya pengetahuan dan informasi yang diperoleh para ibu tentang pola makan yang seimbang. Oleh sebab itu, ibu dengan pola makan yang tidak seimbang, pemenuhan kebutuhan akan protein, mineral, serta zat-zat lain yang diperlukan oleh ibu, bayi dan plasenta tidak akan tercukupi dengan baik.

Jenis makanan yang sering dikonsumsi para ibu hamil di Kabupaten Fakfak ialah makanan pokok (nasi), lauk (ikan), dan sayuran. Ada pula ibu-ibu yang hanya mengkonsumsi makanan pokok (nasi) dengan lauk (ikan) ataupun makanan pokok (nasi) dan sayuran saja. Buah-buahan maupun cemilan sehat di antara jam makan sangat sedikit, begitu pula dengan konsumsi susu. Jenis buah yang kerap dikonsumsi adalah pepaya dan pisang, sedangkan untuk camilan sehat yang kerap dikonsumsi adalah bubur kacang hijau dan biskuit. Sebagian responden mengatakan bahwa mereka akan minum susu bila ingat. Khusus bagi ibu hamil dengan $\mathrm{Hb} 5 \mathrm{gr} / \mathrm{dl}$ akan diberi susu bungkus gratis dari pihak puskesmas. Diketahui bahwa konsumsi buah atau cemilan sehat dan susu masih rendah karena dipengaruhi oleh pendapatan ekonomi yang rendah di wilayah Kabupaten Fakfak, Papua Barat. Tingkat pendidikan yang terbatas dan kegiatan responden yang hanya menjadi seorang ibu rumah tangga turut mempengaruhi pendapatan ekonomi yang rendah tersebut. Pendapatan rata-rata bulanan untuk keluarga responden sekitar Rp 2.000.000,-. Terbatasnya pendapatan bulanan tersebut berpengaruh pula terhadap daya beli keluarga terhadap bahan pangan yang rendah akibat harga jual yang relatif tinggi.

Sriwahyuni et al. (2013) menyatakan bahwa bagi ibu hamil, kekurangan asam folat dapat menyebabkan meningkatnya risiko anemia, sehingga ibu mudah lelah, letih, lesu dan pucat bahkan berpeluang menyebabkan keguguran. Selain itu, vitamin yang didapatkan dari buahbuahan diperlukan untuk memperlancar proses biologis yang berlangsung dalam tubuh ibu dan janin, seperti vitamin $A$, vitamin $B 1$ dan $B 2$, vitamin B6, vitamin B12, vitamin C dan vitamin D.

Masih ditemukan pula ibu yang gemar mengkonsumsi mie instan dengan frekuensi konsumsi 3 kali seminggu. Para ibu beralasan bahwa pengolahan mie instan lebih praktis dan hemat waktu serta harganya relatif lebih murah dibandingkan dengan bahan makanan yang dijual di pasar atau toko. Widodo (2013) menyatakan bahwa dampak negatif makanan cepat saji terhadap kesehatan sangat besar. Makanan cepat saji dapat memicu pertumbuhan sel tubuh yang tidak normal (meningkatkan risiko kanker), membuat pertumbuhan tubuh menjadi abnormal, meningkatkan risiko serangan jantung, membuat ketagihan, meningkatkan berat badan, memicu diabetes dan dapat memicu tekanan darah tinggi. Berdasarkan fakta tersebut dapat dikatakan bahwa keanekaragaman jenis makanan yang dikonsumsi para ibu hamil masih rendah. Selain itu, pemenuhan asupan energinya masih kurang karena tidak sesuai dengan nilai AKG 2013 < 700 kkal selama masa kehamilan).

Salah satu penyebab kurangnya pengetahuan ibu yang sedang hamil di trimester pertama tentang makanan bergizi disebabkan karena pengaruh lingkungan keluarga (Proverawati, 2011). Kondisi ini sejalan dengan penelitian yang dilakukan di Fakfak, ditemukan pasangan baru yang mengganggap kehamilan merupakan kondisi dari masa anak menjadi orang tua sehingga kehamilan dianggap suatu krisis bagi kehidupan berkeluarga yang diikuti oleh stress dan kecemasan. Hal ini berujung dengan terjadi perpecahan antara anggota keluarga. Penting untuk diketahui bahwa trimester pertama kehamilan merupakan saat yang penting bagi ibu hamil karena terjadi pembentukan dan pertumbuhan otak, syaraf, jantung, dan organorgan reproduksi. Kekurangan gizi pada ibu hamil mempunyai dampak yang cukup besar terhadap proses pertumbuhan janin dan anak yang akan dilahirkan.

Selama melakukan penelitian, frekuensi dan porsi makan ibu hamil bergantung pada nafsu 
makan. Hasil uji statistik mengenai frekuensi dan porsi makan menunjukan tidak terdapatnya hubungan antara variabel tersebut dengan kejadian anemia. Sebagian besar responden menjawab frekuensi makannya sebanyak 4 kali dalam sehari ditambah selingan/cemilan. Ada pula responden yang menjawab 1 kali sehari tanpa selingan ataupun 2 kali sehari namun porsinya lebih sedikit dibandingkan sebelum hamil. Frekuensi makan yang baik bagi ibu hamil ialah dengan konsumsi makanan utama 3 kali sehari ditambah 2 kali selingan/cemilan. Porsi makanannya pun harus lebih banyak dari porsi makan sebelum hamil karena selama masa kehamilan ibu membutuhkan tambahan 500 kkal bagi tubuhnya. Kurangnya sosialisasi dari pihak puskesmas setempat menjadikan ibu hamil tidak tahu kapan waktu makan yang tepat untuk makan, bagaimana kebiasaan makan selama masa kehamilan, porsi makan yang tepat, dan jenis makanan apa saja yang baik untuk kehamilan.

Hasil penelitian tersebut tidak sejalan dengan Pertiwi (2013) yang menyatakan bahwa terdapat hubungan antara frekuensi makan dengan kejadian anemia. Kondisi tersebut dapat dijelaskan dari frekuensi makan responden yang tidak teratur, misalnya sehari hanya makan dua kali yaitu pagi dan siang atau siang dan sore saja. Ibu hamil yang memiliki kebiasaan makan utama kurang dari 3 kali sehari sebanyak 24 responden (49\%), namun sebanyak $51 \%$ responden tetap berupaya untuk makan 3 kali perhari, bahkan jika dimungkinkan dapat lebih dengan tujuan untuk mencukupi kebutuhan energi dan zat gizi bagi ibu hamil dan bayinya.

Beberapa ibu hamil masih gemar mengkonsumsi mie instan sebagai makanan sehari-hari, namun tetap memiliki kebiasaan makan yang cukup baik. Para ibu juga kerap memilih makanan cepat saji karena praktis dan mudah dalam penyajiannya, antara lain gorengan, jeroan dan daging berlemak, daging olahan, makanan yang dipanggang, makanan kaleng, olahan keju dan sebagainya. Asupan konsumsi zat energi, protein, lemak, dan karbohidrat yang kurang dapat mempengaruhi pertumbuhan janin didalam kandungan dan dapat mempengaruhi berat badan lahir bayi.
Penelitian Nurhidayati dan Erlyn (2014) menyatakan adanya hubungan yang signifikan antara asupan nutrisi dengan kadar $\mathrm{Hb}$ pada kelompok ibu hamil. Kurangnya asupan nutrisi akan mengakibatkan malnutrisi serta mempengaruhi kecepatan pembentukan $\mathrm{Hb}$ dan konsentrasi dalam darah menurun sehingga menyebabkan kadar $\mathrm{Hb}$ turun. Hal ini terjadi karena zat besi yang tersedia tidak cukup untuk pembentukan $\mathrm{Hb}$, sehingga produksi $\mathrm{Hb}$ lebih rendah. Proses kehamilan sangat memerlukan kebutuhan zat besi. Jika asupan makanan tidak adekuat, terutama dari jenis bahan makanan yang mengandung zat besi, maka tubuh tidak mencukupi untuk sintesis $\mathrm{Hb}$ karena defisiensi besi walaupun eritrosit tetap diproduksi dalam jumlah biasa akan tetapi kandungannya lebih rendah dari normal dan berukuran lebih kecil sehingga kurang mampu mengangkut oksigen. Apabila kandungan zat besi yang terkandung dalam makanan sedikit, maka kemungkinan terjadinya anemia akan semakin besar.

Suplemen zat besi ( $\mathrm{Fe}$ ) adalah tablet yang berisi $60 \mathrm{mg}$ elemental iron dan $0,25 \mathrm{mg}$ asam folat pada setiap tablet. Ibu hamil perlu mengonsumsi suplemen Fe selama kehamilan karena kebutuhan zat besi ibu hamil meningkat selama kehamilan (Salman et al, 2016). Rata-rata kebutuhan zat besi pada wanita hamil berkisar antara $800-1.040 \mathrm{mg}$. Kebutuhan tersebut diperkirakan sekitar $300 \mathrm{mg}$ yang diperlukan untuk janin, sekitar $50-75 \mathrm{mg}$ untuk pembentukan plasenta, dan sekitar $500 \mathrm{mg}$ lagi digunakan untuk meningkatkan massa haemoglobin maternal. Kurang lebih 200 mg lebih akan dieksresikan lewat usus, urin, dan kulit (Arisman, 2004).

Setiap 100 kalori dalam makanan yang dikonsumsi oleh ibu hamil akan menghasilkan sekitar 8 - $10 \mathrm{mg}$ zat besi (Manuaba, 2001). Perhitungan makan 3 kali sehari dengan 2.500 kalori akan menghasilkan sekitar $20-25$ mg zat besi per hari. Selama kehamilan dengan perhitungan 288 hari, ibu hamil akan menghasilkan zat besi sebanyak $100 \mathrm{mg}$, sehingga kebutuhan zat besi masih kekurangan untuk wanita hamil. Semakin sering seorang wanita hamil dan melahirkan, maka ibu akan banyak kehilangan zat besi dan mengalami anemia berat (Manuaba, 2007). 
Tingkat kepatuhan konsumsi tablet Fe selama hamil dinilai berdasarkan keseluruhan jumlah tablet Fe yang diminum selama hamil. Seorang ibu dikatakan patuh jika selama hamil mengkonsumsi sebanyak 90 tablet Fe atau lebih dan dikatakan tidak patuh apabila mengkonsumsi tablet Fe kurang dari 90 tablet. Para ibu hamil di Kabupaten Fakfak yang memeriksakan kehamilannya di Puskesmas, jika diketahui memiliki kadar $\mathrm{Hb}$ yang rendah, petugas kesehatan memberikan tablet Fe secara gratis. Apabila pemeriksaan kadar $\mathrm{Hb}$ selanjutnya normal, maka pemberian tablet dihentikan.

Berdasarkan hasil penelitian, ditemukan adanya hubungan antara konsumsi tablet (Fe) dengan kejadian anemia. Berdasarkan hasil observasi di lapangan, tidak semua ibu hamil didapati rutin mengonsumsi tablet Fe. Para ibu yang mengalami anemia dihimbau oleh pihak puskesmas untuk mengkonsumsi tablet Fe setiap hari, namun pada kenyataannya sebanyak 6 orang responden hanya mengkonsumsi tablet Fe 3 kali seminggu. Hal tersebut sejalan dengan hasil penelitian Sifik dan Nanang (2014) yang menyatakan bahwa terdapat hubungan yang signifikan dan positif antara sikap kepatuhan ibu dalam mengkonsumsi tablet Fe dan kadar $\mathrm{Hb}$ ibu hamil yang berkunjung di Puskesmas Kecamatan Palmerah. Oleh karena itu, semakin tinggi sikap kepatuhan ibu hamil dalam mengkonsumsi suplemen zat besi, maka semakin tinggi kadar $\mathrm{Hb}$ ibu hamil tersebut. Anemia akibat ketidakpatuhan dalam konsumsi tablet Fe diduga disebabkan oleh rasa malas, bosan, muncul anggapan tidak penting untuk mengkonsumsi tablet Fe, lupa, hingga efek samping dari tablet yang membuat tidak nyaman responden seperti mual, muntah, bau, dan tidak enak. Konsumsi makanan yang kurang seimbang (makanan sumber besi heme dan non heme) secara bersamaan juga menjadi salah satu penyebab anemia.

Anemia pada ibu hamil pada prinsipnya dapat dicegah sejak dini. Selain melakukan pemeriksaan kesehatan secara rutin, anemia dapat dicegah pula dengan mengkonsumsi makanan bergizi seimbang yang cukup mengandung asupan zat besi (Ertiana et al, 2016). Ibu hamil pun diharapkan tetap mampu berpikir kreatif untuk membuat modifikasi makanan pokok yang mengandung zat besi untuk menghindari kejenuhan dalam konsumsi seharihari (Arisman, 2004). Pihak puskesmas maupun penyedia layanan kesehatan perlu melakukan pendekatan kepada tokoh masyarakat maupun langsung kepada setiap keluarga untuk mengkampanyekan kesadaran dalam melakukan pemeriksaan kehamilan secara berkala dan pentingnya asupan nutrisi bagi perkembangan dan kesehatan ibu serta janin, salah satunya adalah untuk mencegah anemia. Fatimah et al. (2017) menyatakan bahwa upaya penyuluhan tidak hanya dilakukan secara berkelompok, tetapi juga mandiri guna meningkatkan kepatuhan ibu hamil dalam mengkonsumsi tablet Fe.

\section{Kesimpulan}

Perilaku makan ibu hamil diketiga Puskesmas di Kabupaten Fakfak, Papua Barat berdasarkan jenis, porsi, frekuensi, dan kebiasaan makan tidak memiliki hubungan signifikan dengan kejadian anemia. Kepatuhan terhadap konsumsi suplemen zat besi berpengaruh secara signifikan terhadap kejadian anemia pada ibu hamil dengan nilai signifikansi 0.001. Ibu hamil dan keluarga diharapkan lebih proaktif untuk memeriksakan kehamilannya serta memperbaiki perilaku makan dengan memperhatikan jenis dan kebiasaan dalam memilih dan mengolah makanan serta mengatur porsi dan frekuensi makan dan selingan sehat serta diimbangi dengan tetap mengkonsumsi suplemen tablet Fe guna mencegah anemia. Ibu hamil diharapkan pula rutin memeriksakan diri kepada dokter, bidan, atau tenaga kesehatan setempat yang ditunjuk serta berkonsultasi dengan ahli gizi di puskesmas untuk mengoptimalkan asupan zat gizi yang tepat selama masa kehamilan demi kesehatan dan keselamatan ibu selama proses mengandung hingga persalinan.

\section{Bibliografi}

1. Arisman. 2004. Gizi dalam Daur Kehidupan. Jakarta: EGC.

2. Ariyani, R. 2016. Faktor-faktor yang Mempengaruhi Kejadian Anemia pada Ibu Hamil Trimester III di Wilayah Kerja Puskesmas Mojolaban Kabupaten Sukoharjo. Naskah Publikasi.

3. Balitbang Kemenkes RI. 2013. Riset Kesehatan Dasar; RISKESDAS. Jakarta: Balitbang Kemenkes RI. 
4. Ertiana, D. dan Astutik, R. Y. 2016. Adanya Anemia pada Kehamilan Trimester II dapat Mengakibatkan Tidak Normalnya Berat Badan Bayi Baru Lahir di Wilayah Kerja Puskesmas Bendo, Kabupaten Kediri. Jurnal Sain Med. 8 (2): 124 - 129.

5. Fatimah, S., Ananyi, Y., dan Tomboka, E. I. 2017. Hubungan Kepatuhan Minum Tablet Fe dengan Anemia Ibu Hamil di Wilayah Kerja Puskemas Grabag II, Kabupaten Magelang. Journal of Health. 4 (1): 27 31.

6. Francin, P. 2005. Gizi dalam Kesehatan Reproduksi. Jakarta: EGC.

7. Hendrayani, M. D., Sawitri, A. A. S., dan Karmaya, M. 2013. Perilaku Pemeriksaan Antenatal sebagai Faktor Risiko Anemia Gizi Ibu Hamil di Puskesmas II Denpasar Selatan Tahun 2012. Public Health and Preventive Medicine Archive. 1 (1).

8. Kusumastuti, P. 2015. Hubungan Sikap Ibu Hamil dalam Pemeriksaan Kehamilan dengan Keteraturan Kunjungan Antenatal Care (ANC) di Puskesmas Sewon II Bantul. Naskah Publikasi.

9. Manuaba, I. B. G. 2001. IImu Kebidanan, Penyakit Kandungan dan Keluarga Berencana Untuk Pendidikan Bidan. Jakarta: EGC.

10. Manuaba, I. B. G. 2007. Buku Ajar Ginekologi. Jakarta: EGC.

11. Nurhidayati, A. dan Erlyn, H. 2014. Hubungan Asupan Nutrisi dengan Kadar Hb pada Ibu Hamil di BPS Suratini Suwarno Surakarta. Jurnal KesMaDaSka. Januari: $21-27$.

12. Pertiwi, A. S. 2013. Hubungan antara Pola Makan dengan Kejadian Anemia pada Ibu Hamil di Wilayah Kerja Puskesmas Kerjo Kabupaten Karanganyar. Naskah Publikasi.

13. Proverawati, A. 2011. Anemia dan Anemia Kehamilan. Yogyakarta: Nuha medika.

14. Salman, Y., Ideris, dan Siti, M. M. 2016. Hubungan Pola Konsumsi Zat Besi dan Kepatuhan Mengkonsumsi Tablet Fe dengan Kejadian Anemia pada Ibu Hamil di Wilayah Kerja Puskesmas Sambung Makmur Tahun 2015. Jurkessia. 6 (2): 51 - 58.

15. Sifik dan Nanang, P. 2010. Sikap Kepatuhan Konsumsi Tablet Fe terhadap Kadar Hb lbu Hamil yang Berkunjung ke Puskesmas Kecamatan Palmerah Kota Administrasi Jakarta Barat. Jurnal Gizi. 2 (2).

16. Sriwahyuni., Rahayu, I., dan Abdul, S. 2013. Pola Konsumsi Buah dan Sayur serta Asupan Zat Gizi Mikro dan Serat pada Ibu Hamil di Kabupaten Gowa 2013. Program Studi IImu Gizi, Fakutas Kesehatan Masyarakat, Universitas Hasanuddin, Makasar. Repository Hasanuddin University.

17. Syari, M., Joserizal S., dan Ulvi, M. 2015. Peran
Asupan Zat Gizi Makronutrien Ibu Hamil terhadap Berat Badan Lahir Bayi di Kota Padang. Jurnal Kesehatan Andalas. 4 (3): 729 - 736

18. Wahyuningsih, I. S. dan Sri, E. W. 2013. Hubungan Pola Makan dengan Kejadian Anemia pada Ibu Hamil di Bidan Praktik Mandiri Kabupaten Demak. Dinamika Kebidanan. 3 (1): 1 - 9.

19. WHO. 2008. WHO report on the Global Tobacco Epidemic. WHO.

20. Widodo, T. 2013. Respon Konsumen terhadap Produk Makanan Instan (Studi Kasus di Pasar Raya Kota Salatiga). Among Makarti. 6 (12): 10 - 28.

21. Zulaikha, E. dan Umu, H. E. N. 2015. Hubungan Pola Makan dengan Kejadian Anemia pada Ibu Hamil Trimester III di Puskesmas Pleret Bantul. Naskah Publikasi. 